\title{
Correlation of offshore seismic profiles with onshore New Jersey Miocene sediments
}

\author{
D.H. Monteverde ${ }^{\mathrm{a}, \mathrm{b}, *}$, K.G. Miller ${ }^{\mathrm{b}, \mathrm{c}}$, G.S. Mountain ${ }^{\mathrm{c}}$ \\ ${ }^{a}$ New Jersey Geological Survey, P.O. Box 427, Trenton, NJ 08625, USA \\ ${ }^{\mathrm{b}}$ Department of Geological Sciences, Rutgers University, Piscataway, NJ 08854, USA \\ ${ }^{\mathrm{c}}$ Lamont-Doherty Earth Observatory of Columbia University, Palisades, NY 10964, USA
}

\begin{abstract}
The New Jersey passive continental margin records the interaction of sequences and sea-level, although previous studies linking seismically defined sequences, borehole control, and global $\delta^{18} \mathrm{O}$ records were hindered by a seismic data gap on the inner-shelf. We describe new seismic data from the innermost New Jersey shelf that tie offshore seismic stratigraphy directly to onshore boreholes. These data link the onshore boreholes to existing seismic grids across the outer margin and to boreholes on the continental slope. Surfaces defined by age; facies, and log signature in the onshore boreholes at the base of sequences Kw $2 \mathrm{~b}$, $\mathrm{Kw} 2 \mathrm{a}, \mathrm{Kw} 1 \mathrm{c}$, and $\mathrm{Kw} 0$ are now tied to seismic sequence boundaries $\mathrm{m} 5 \mathrm{~s}, \mathrm{~m} 5.2 \mathrm{~s}$, m5.4s, and m6s, respectively, defined beneath the inner shelf. Sequence boundaries recognized in onshore boreholes and inner shelf seismic profiles apparently correlate with reflections $\mathrm{m} 5, \mathrm{~m} 5.2, \mathrm{~m} 5.4$, and $\mathrm{m} 6$, respectively, that were dated at slope boreholes during ODP Leg 150 . We now recognize an additional sequence boundary beneath the shelf that we name m5.5s and correlate to the base of the onshore sequence Kw1b. The new seismic data image prograding Oligocene clinoforms beneath the inner shelf, consistent with the results from onshore boreholes. A land-based seismic profile crossing the Island Beach borehole reveals reflector geometries that we tie to Lower Miocene litho- and bio-facies in this borehole. These land-based seismic profiles image well-defined sequence boundaries, onlap and downlap truncations that correlate to Transgressive Systems Tracts (TST) and Highstand Systems Tracts (HST) identified in boreholes. Preliminary analysis of $\mathrm{CH0698}$ data continues these system tract delineations across the inner shelf. The CH0698 seismic profiles tie seismically defined sequence boundaries with sequences identified by lithiologic and paleontologic criteria. Both can now be related to global $\delta^{18} \mathrm{O}$ increases and attendant glacioeustatic lowerings. This integration of core, $\log$, and seismic character of mid-Tertiary sediments across the width of the New Jersey margin is a major step in the longstanding effort to evaluate the impact of glacioeustasy on siliciclastic sediments of a passive continental margin. (C) 2000 Elsevier Science B.V. All rights reserved.
\end{abstract}

Keywords: siesmic stratigraphy; sea-level change; Miocene; sequences; systems tracts

\section{Introduction}

Seismic profiles show that the New Jersey continental shelf contains a thick record of prograding

\footnotetext{
* Corresponding author. New Jersey Geological Survey, P.O. Box 427, Trenton, NJ 08625, USA. Fax: + 1-609-292-2576.

E-mail address: donm@njgs.dep.state.nj.us (D.H. Monteverde).
}

clinoform wedges. First recognized by Schlee (1981) and interpreted as prograding deltas, many of the clinoformal reflections have since been documented as sequence boundaries (Greenlee et al., 1988, 1992; Greenlee and Moore, 1988) based on classic criteria of onlap, downlap, and offlap (erosional truncation and toplap) (Christie-Blick and Driscoll, 1995; Mitchum, 1977). Similar prograding clinoform 


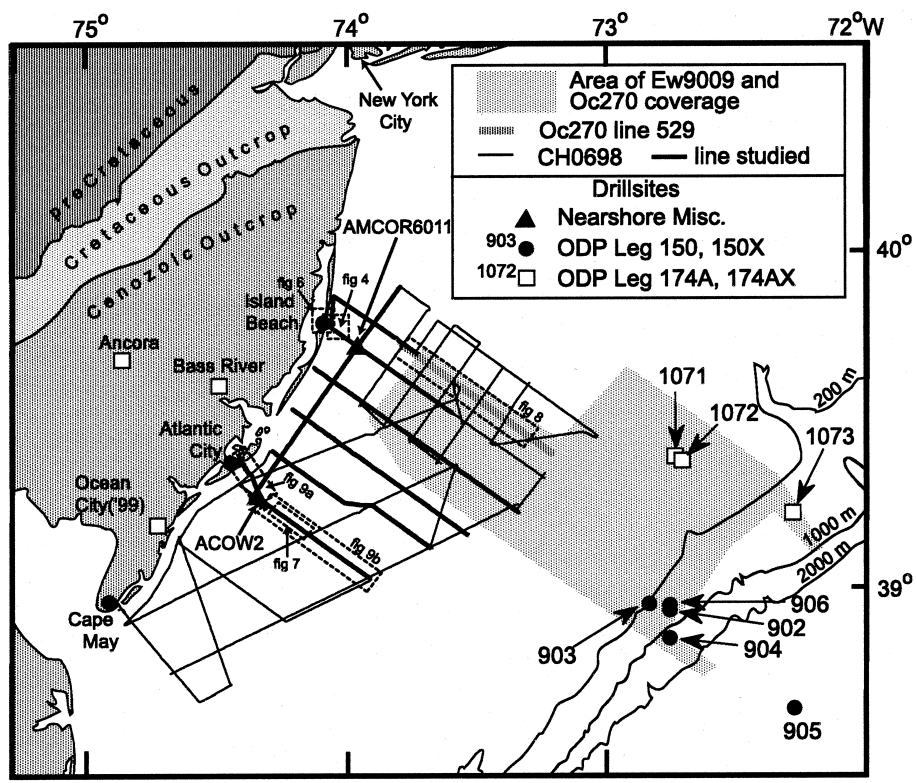

Fig. 1. Location map showing the CH0698, Oc270 and Ew9009 seismic grids, offshore ODP Legs 150 and 174A, onshore ODP Legs 150X and 174AX and nearshore AMCOR6011 and ACOW2 sites. CH0698 lines 9, 14, 17, 19 and 27 are used in other figures as noted and described in the text.

wedges are observed in Neogene sediments of passive and active margins throughout the world (Bartek et al., 1991), indicating a common link to global climate and glacioeustatic change as recorded by global $\delta^{18} \mathrm{O}$ variations (Miller et al., 1991). While most of these wide-ranging clinoforms are Miocene and younger, the age of the initiation of large-scale progradation has been poorly documented and ranges from Oligocene (Greenlee et al., 1988; Bartek et al., 1991) to Late Eocene (Pekar et al., 2000).

The prograding? Oligocene-Recent clinoforms beneath the New Jersey shelf provide an opportunity to evaluate the relationships between sequences and sea-level change (Miller and Mountain, 1994). This period of Earth history is associated with the growth and decay of large continental ice sheets recorded by global $\delta^{18} \mathrm{O}$ variations (Miller et al., 1991). The Ocean Drilling Program (ODP) chose the New Jersey margin to drill a borehole transect from the slope to the coastal plain (Fig. 1; Miller and Mountain, 1994) to test the relationship between sequences, sea level and $\delta^{18} \mathrm{O}$ variations. Although drilling originally targeted shelf locations where seismic facies are best imaged (Miller and Mountain, 1994), safety considerations required initial drilling on the slope (ODP
Leg 150; Mountain et al., 1994) and onshore (ODP Leg 150X; Miller et al., 1994, 1996a). In 1997, drilling edged onto the outer continental shelf (ODP Leg 174A; Austin et al., 1998), targeting Late Neogene clinoforms (see Metzger et al., 2000).

Previous onshore studies by the New Jersey coastal plain drilling project (ODP Legs 150X and 174AX) recognized Cenozoic sequences in onshore boreholes by integrating physical evidence for erosion with age and biofacies/lithofacies changes (Miller et al., 1994, 1996a; Miller and Snyder, 1997). Studies based on seismic geometries have recognized sequences beneath the continental shelf and have traced them to slope boreholes (ODP Leg 150), where they have been dated as Eocene to Recent (Mountain et al., 1994; Miller et al., 1996b). The ages of the sequences are similar onshore and offshore, and both sets correlate with deep-sea $\delta^{18} \mathrm{O}$ increases (Fig. 2), thereby indicating glacioeustatic control on sequence development (Miller et al., 1996a, 1996b, 1998).

Despite these efforts, there has been: (1) inadequate direct sampling of Oligocene-middle Miocene strata beneath the shelf where the record is most sensitive to sea-level change; and (2) inadequate seismic coverage 


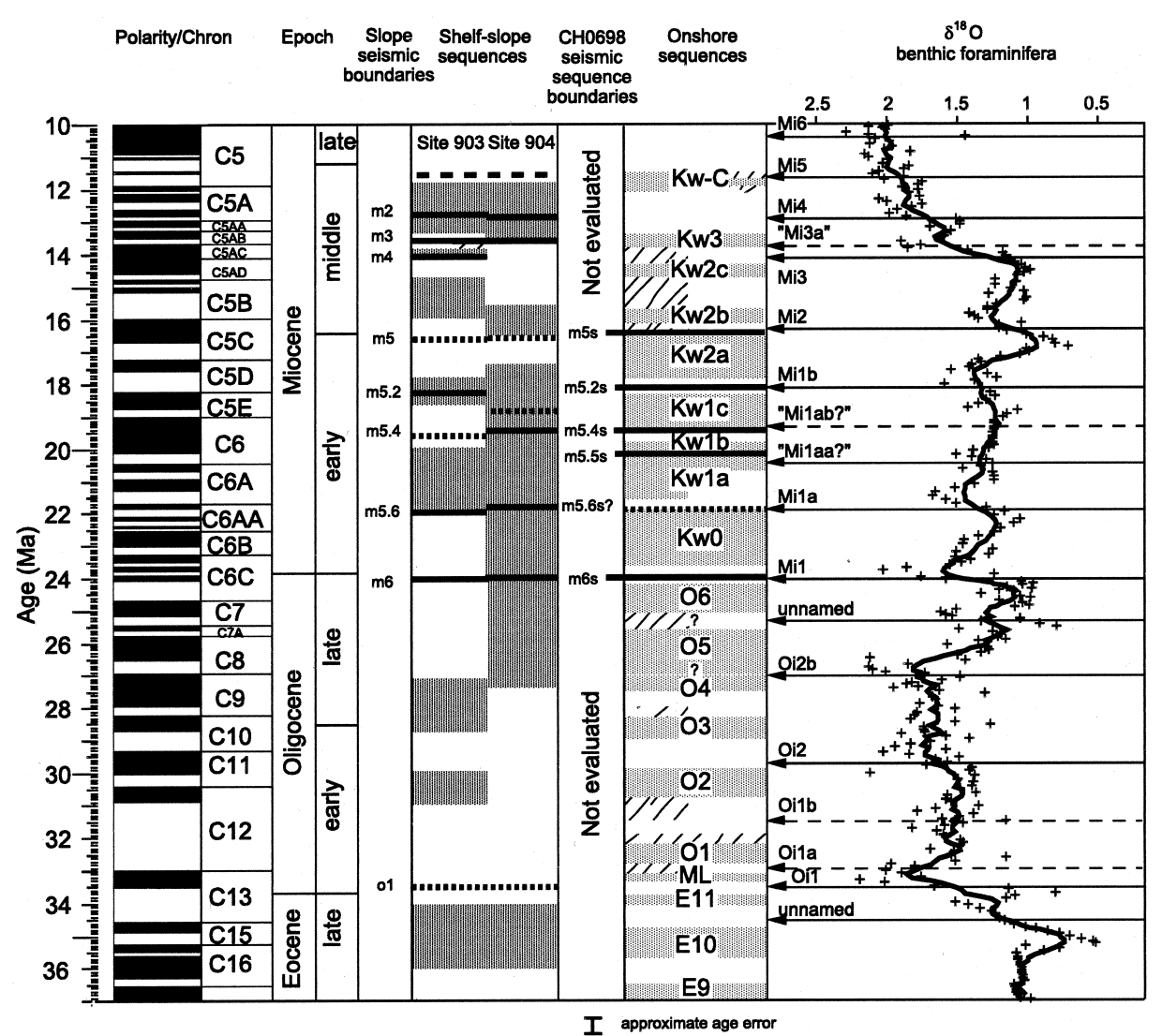

Fig. 2. Revised comparison of Oligocene-Miocene slope sequences, onshore sequences and CH0698 seismic sequence. Modified from Miller et al. (1998).

in the nearshore zone, a critical region linking onshore and offshore stratigraphy. Middle Miocene sequences are best developed beneath the middle New Jersey shelf where they have been well imaged by two profile grids (Fig. 1; Ew9009, Miller and Mountain, 1994; Oc270, Austin et al., 1996), whereas Lower Miocene sediments are best developed beneath the inner shelf. These Lower-Middle Miocene sediments have not been sampled in the optimal locations: the oldest strata sampled by Leg 174A are about $12 \mathrm{Ma}$ (Austin et al., 1998), whereas the Lower-Middle Miocene sections sampled onshore generally represent only proximal facies deposited well landward of the clinoform inflection points. Although the onshore sites sampled Oligocene-Lower Miocene sediments that are relatively complete and potentially represent critical clinoformal facies, until now correlation of onshore boreholes with offshore seismic profiles has straddled a gap in seismic coverage of several tens of kilometers.

With $\mathrm{CH} 0698$ seismic data we are now able to correlate directly well sampled onshore Lower to Middle Miocene sections to offshore seismic sequences. This provides ground-truth to offshore Miocene seismic facies by comparing each with facies interpretations derived from litho- and bio-facies studies at the onshore boreholes. Furthermore, these correlations provide a firm basis for locating future offshore drill sites at the positions most critical to understanding the relationship between stratal geometry and sea-level change.

\section{Methods}

Marine multichannel seismic profiles form the basis 


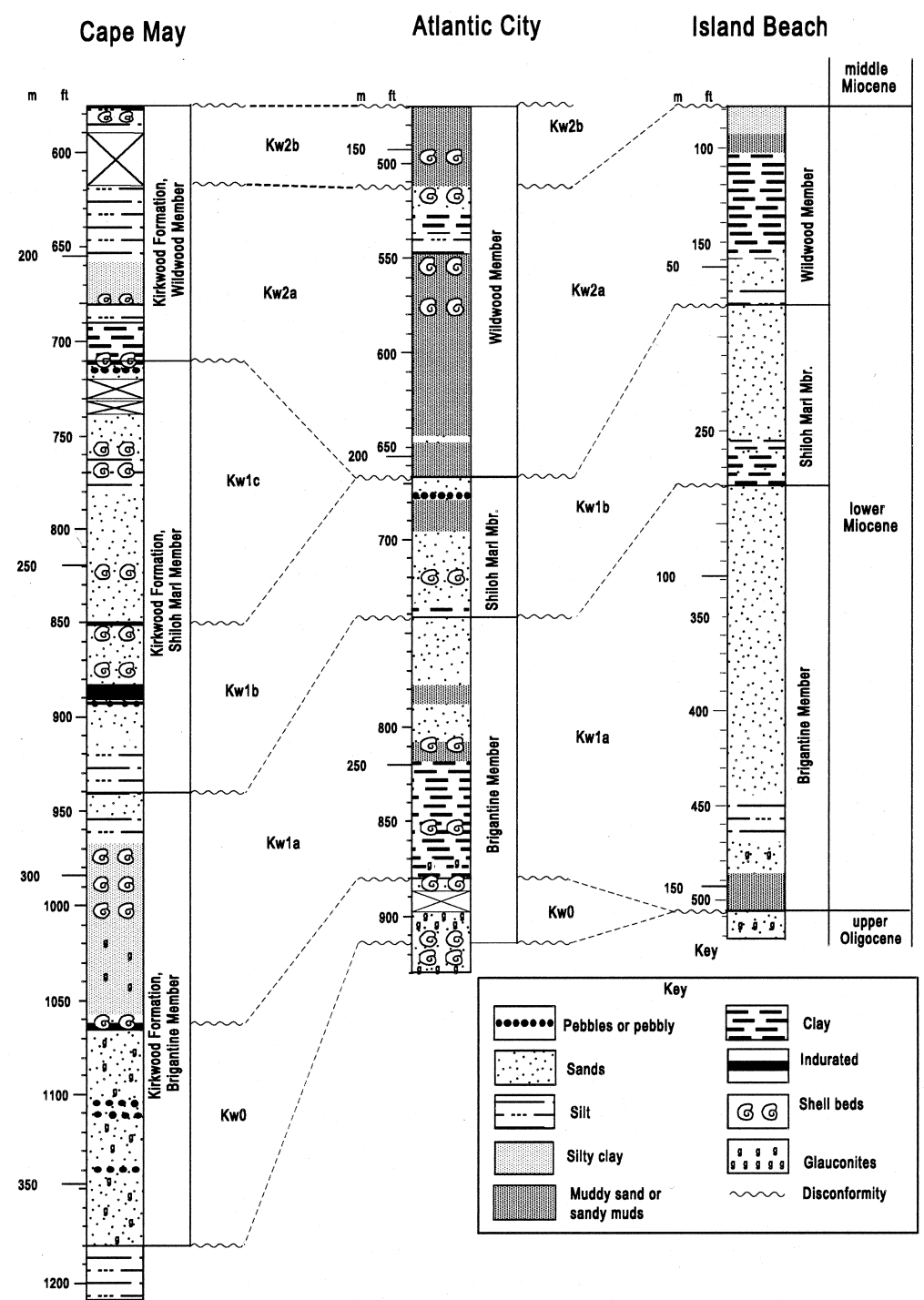

Fig. 3. Comparison of Lower Miocene lithologic units, sequences, and chronostratigraphic units at Island Beach, Atlantic City, and Cape May. Modified after Miller (1997).

of this study, supplemented by an onshore seismic profile published by Miller et al. (1996c). We used reflection geometries seen in these high-resolution data to define Oligocene and Lower Miocene seismic sequences that we traced through the data grid and tied into boreholes using synthetic seismograms and time-depth relationships. The seismic character of onshore and offshore sequences was directly compared to borehole lithologies and ages derived from biostratigraphic and isotropic studies (Fig. 3; Miller et al., 1994, 1996a).

\subsection{Offshore seismic data}

MCS profiles were collected aboard the $R / V$ Cape Hatteras using the Lamont-Doherty Earth Observatory (LDEO) HiRes MCS system in May 1998. $1100 \mathrm{~km}$ of profiles that link onshore boreholes to 


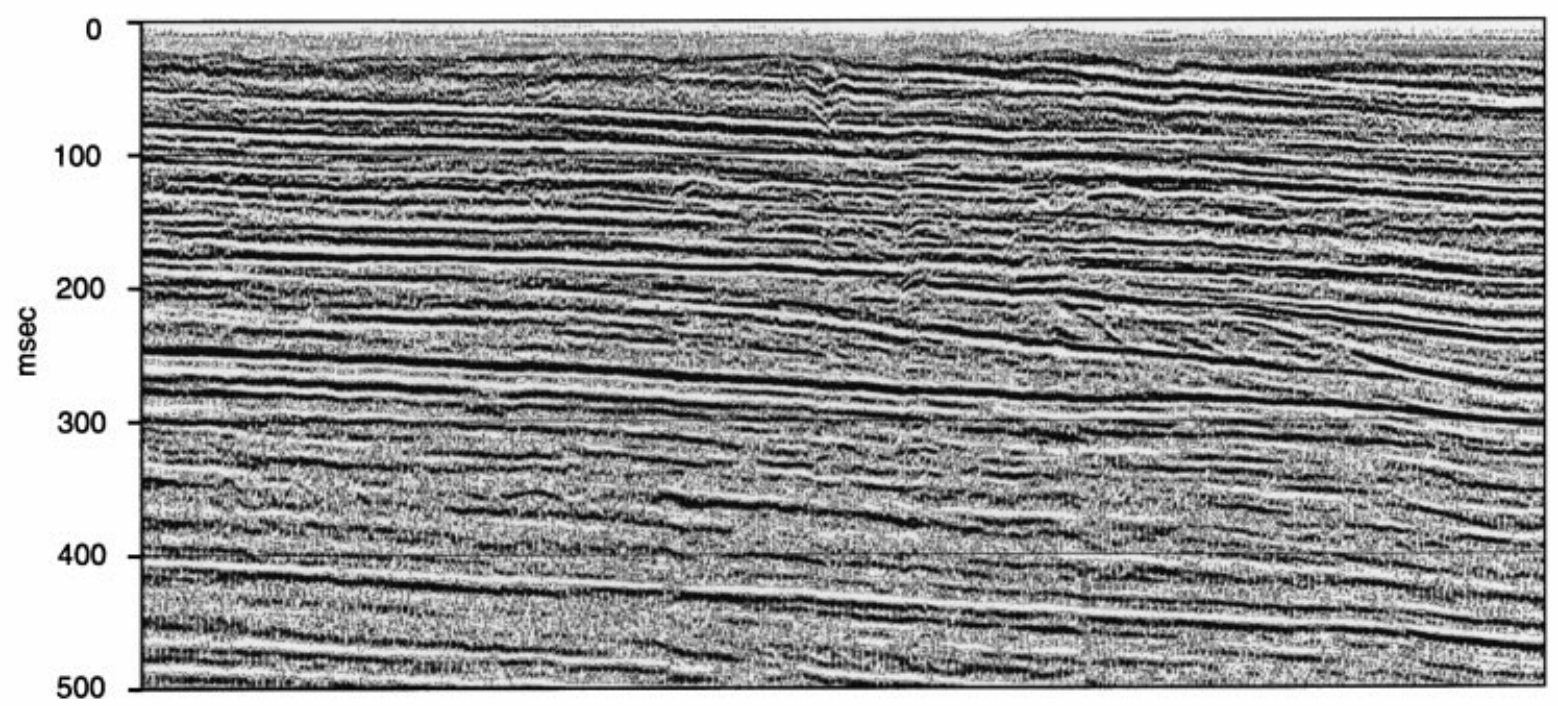

Island Beach

synthetic seismogram

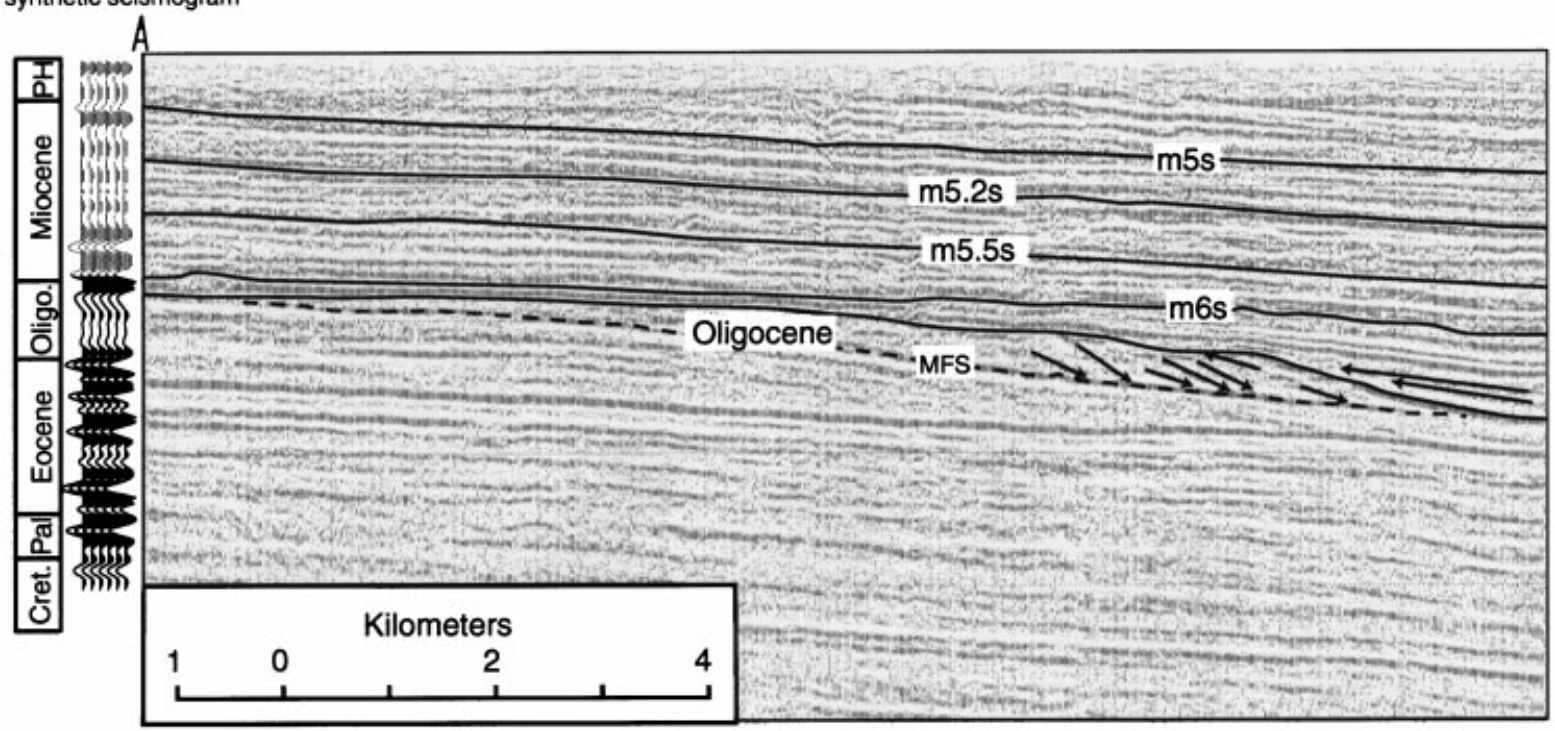

Fig. 4. Synthetic seismogram derived from the Island Beach acoustic log projected onto CH0698 line 14. The upper part of the sonic log (in gray on the synthetic seismogram) was run through the casing and imaged reflectors should be disregarded. Ages depicted to the left of the synthetic seismogram result from detailed study of Island Beach borehole (PH is Pleistocene through Holocene, Miller et al., 1994). m5s, m5.2s, m5.5s and m6s are seismic sequence boundaries that were traced around the CH0698 seismic grid. The m6s seismic sequence boundary was also identified with the seismogram. Seismic terminations identified a new Oligocene clinoform inflection that appears below m6s.

existing profiles extending seaward to boreholes on the outermost shelf and upper slope were obtained (Fig. 1). Three onshore boreholes were approached as close as possible: we sailed directly into Cape
May inlet, collecting underway data to within $\sim 700 \mathrm{~m}$ of the Leg 150X borehole (Miller et al., 1996a); we collected data while leaving Absecon inlet, $700 \mathrm{~m}$ from the Atlantic City borehole (Fig. 9) 

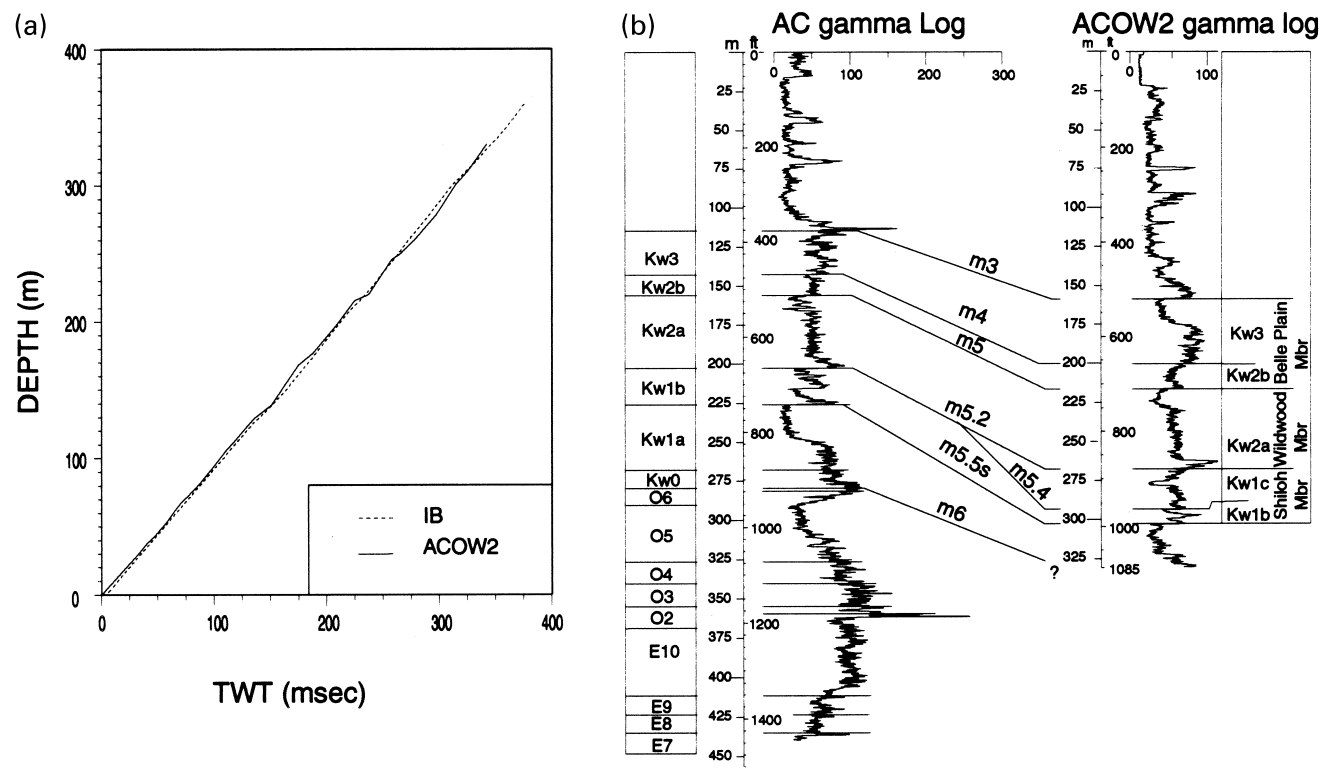

Fig. 5. (a) Acoustic data plotted as depth vs. two-way traveltime (TWT) from Island Beach and ACOW2. The Island Beach data are derived from a downhole sonic log (Miller et al., 1994), whereas the ACOW2 data are derived from a check shot survey (Waldner and Hall, 1991) recalculated from interval velocities back to depth vs. TWT. (b) Correlation based on gamma logs from the Atlantic City borehole and the ACOW2 well. Sequence stratigraphy at Atlantic City is based on physical and biostratigraphic criteria of continuously drilled core samples (Miller et al., 1997), whereas at the ACOW2 well, we interpreted the litho- and log stratigraphy of Owens et al. (1995) in terms of the Kw sequences of (Miller et al., 1997).

(Miller et al., 1997); and we acquired an offshore strike line that at its closest approach was $1500 \mathrm{~m}$ from the Island Beach borehole (Fig. 4) (Miller et al., 1997). In addition, we acquired three grids of closely spaced profiles that meet the guidelines for safety assessment (Sea level working group, 1992) across additional proposed drill sites (Miller et al., 1998).

The LDEO MCS system used a 45/45 cu-in Generator-Injector airgun towed at approximately $2 \mathrm{~m}$ depth. A 48-channel, $600 \mathrm{~m}$ solid (not oil-filled) ITI streamer was maintained at $2 \pm 0.5 \mathrm{~m}$ depth with a near trace source offset of zero. Ship speed, monitored by DGPS, was maintained at $4.9 \mathrm{~km}$ over the seafloor to yield $12.5 \mathrm{~m}$ between shots at $5 \mathrm{~s}$ intervals. The data were recorded with an OYO DAS-1 at a $0.5 \mathrm{~ms}$ sample rate; trace lengths were $2 \mathrm{~s}$. Preliminary processing has been completed on several lines and includes outside mute, velocity analysis, Normal Moveout (NMO) correction, bandpass filtering, spreading loss correction, predictive deconvolution, Stolt migration, and time-varying gain. The data are of excellent quality with vertical resolution approach- ing $5 \mathrm{~m}$ and usable acoustic imaging to approximately $1 \mathrm{~s}$ of two-way traveltime.

For this study we analyzed five CH0698 dip lines and two strike lines (Fig. 1) that have been processed thus far, detailing features from Atlantic City northward. Miocene sequences generally thicken and are more numerous downdip; because of the oblique strike of Miocene strata relative to the modern coastline, the Island Beach, Atlantic City, and Cape May boreholes sample progressively downdip sections. Thus, future studies of the southern portion of the dataset between Atlantic City and Cape May, yet to be prepared, are expected to provide better coverage of Lower to Middle Miocene strata (e.g. the Kw1c, Kw2c, and KwCohansey sequences are only found at Cape May; Fig. 2; Miller et al., 1996a).

\subsection{Synthetic seismogram, depth-time relationships, and seismic borehole correlations}

The wireline sonic $\log$ at the Leg 150X Island 
Beach borehole provides the depth-to-acoustic-traveltime conversion needed to firmly tie features in the rock record to reflections in nearby seismic profiles. Accordingly, a $50 \mathrm{~Hz}$ Ricker wavelet (similar to the CH0698 seismic source) was convolved with the acoustic log to create a synthetic seismogram (Metzger, pers. comm.). Using the Miocene strike direction provided by Miller et al. (1997) as a guide, the synthetic seismogram was projected $1800 \mathrm{~m}$ northeast to cdp 9450 of CH0698 line 14 (Fig. 4, see location map Fig. 6). The data quality is good and we find a close match between the synthetic and observed seismic data for the prediction of reflection m6s. The seismic match for older stratigraphy below this is reasonable but not as close. There is no correspondence for the interval from 0 to $0.148 \mathrm{~ms}$ subsurface where the sonic log was run through casing (Fig. 4, gray section of synthetic). Geophysical logs aided in the correlation of the seismic boundaries. The Atlantic City Offshore Well 2 (ACOW2) borehole contained gamma ray and check shot surveys; interval velocities derived from the latter (Waldner and Hall, 1991) were recalculated as depth vs. time and compared to a depth vs. time plot derived from the Island Beach sonic log. These two datasets match closely (Fig. 5a), adding confidence to our depth-time correlations at the Island Beach projection to $\mathrm{CH} 0698$ line 14 as well as to the projections of Atlantic Margin Coring Project borehole 6011 (AMCOR6011, Hathaway et al., 1976, 1979), ACOW2, and Atlantic City borehole data into the seismic grid.

ACOW2 data not only allowed an evaluation of the Island Beach depth-traveltime function, but also allowed direct correlation of sequences identified in boreholes with those observed in seismic profiles. The late Owens (Owens et al., 1995) identified subsurface Miocene coastal plain formations based on the drill cuttings and gamma ray log character for the ACOW2 borehole. We placed the formation picks of Owens et al. (1995) into the Miocene sequence terminology of Miller et al. (1997) (Fig. 5b). We extended these correlations using gamma ray logs to the Atlantic City borehole, matching the sequence usage of Miller et al. (1994, 1996b, 1997, 1998) (Fig. 5b). Sequence boundaries from two sites (ACOW2 and Atlantic City) were projected into seismic lines 9 (ACOW2) and 27 (Atlantic City) using the Island Beach/ ACOW2 depth-time relationship (Fig. 9). The
AMCOR6011 offshore well provided a correlation for Oligocene/Miocene sequence boundary, m6 (Pekar et al., 2000).

\subsection{Land seismic and facies analysis}

The ODP Leg 150X Island Beach borehole was drilled $250 \mathrm{~m}$ from a high-resolution, $\mathrm{N}-\mathrm{S}$ oriented land reflection profile collected previously by Miller et al. (1996c) (Fig. 6). These seismic data were based on the summed impacts from a $4.5-\mathrm{kg}$ hand-held sledge hammer that provided $225-245 \mathrm{~Hz}$ source frequencies at $5 \mathrm{~m}$ spacings. Walkaway noise tests provided optimum source-geophone offsets and allowed at least $180 \mathrm{~m}$ depth penetration. A geophone array provided 6-fold stacking after trace editing, inside mute, velocity analyses every 5-10 m along line, and Normal Moveout correction. Deconvolution, bandpass filtering at $150-350 \mathrm{~Hz}$ and time-varying gain resulted in vertical resolution that approached $1 \mathrm{~m}$ (Miller et al., 1996c).

A graphic lithologic description and gamma ray log of the Miocene-Holocene section recovered at the Island Beach Leg $150 \mathrm{X}$ borehole was scaled to the seismic profile published by Miller et al. (1996c) using their stacking velocities (Fig. 6). Lower Miocene sequence boundaries recognized by physical and log character (Miller et al., 1994, 1997) closely match seismic surfaces defined by reflector terminations (Fig. 6). However, the placement of the boundary between sequences $\mathrm{Kw} 1 \mathrm{a}$ and $\mathrm{Kw} \mathrm{lb}$ remains uncertain: Miller et al. (1994) originally placed the base of the Kw1b sequence at a surface at $85 \mathrm{~m}$ $(279 \mathrm{ft})$. After Owens et al. (1997) noted a distinct facies overstep associated with a surface at $92.3 \mathrm{~m}$ (303 ft), Miller et al. (1997) moved the base of $\mathrm{Kw} 1 \mathrm{~b}$ to this level, interpreting the surface at $85 \mathrm{~m}$ $(279 \mathrm{ft})$ as a maximum flooding surface (MFS). Miocene age control at Island Beach is poor: the entire $\mathrm{Kw} 2 \mathrm{a}$ sequence is simply assigned 'Lower East Coast Diatom Zone 2 (ECDZ2)", and Sr-isotopic ages are available only for the base of the Kwla sequence (Miller et al., 1994). Age control on the upper Pleistocene to Holocene is provided by Accelerator Mass Spectrometry (AMS) ${ }^{14} \mathrm{C}$ dates (Miller et al., 1994). Sugarman and Miller (1996) and Miller et al. (1997) provide facies interpretations for this section using lithologic and paleontologic criteria. 


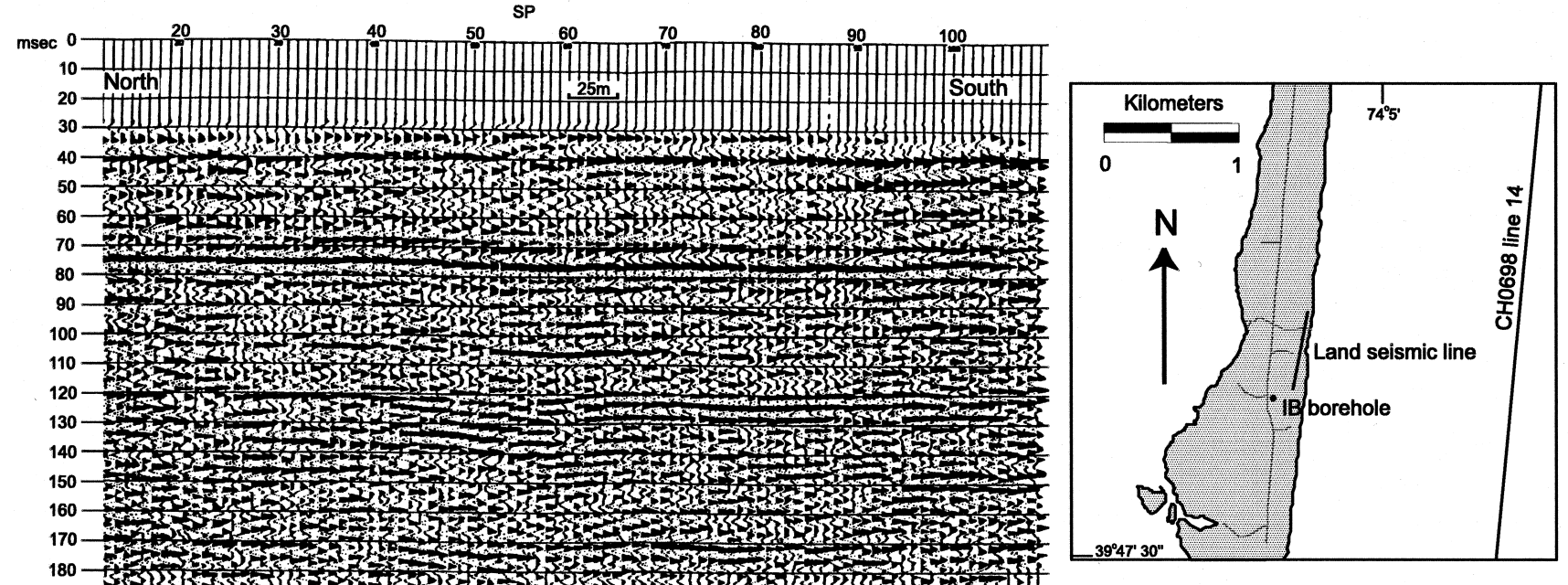

$180-$ Shaj

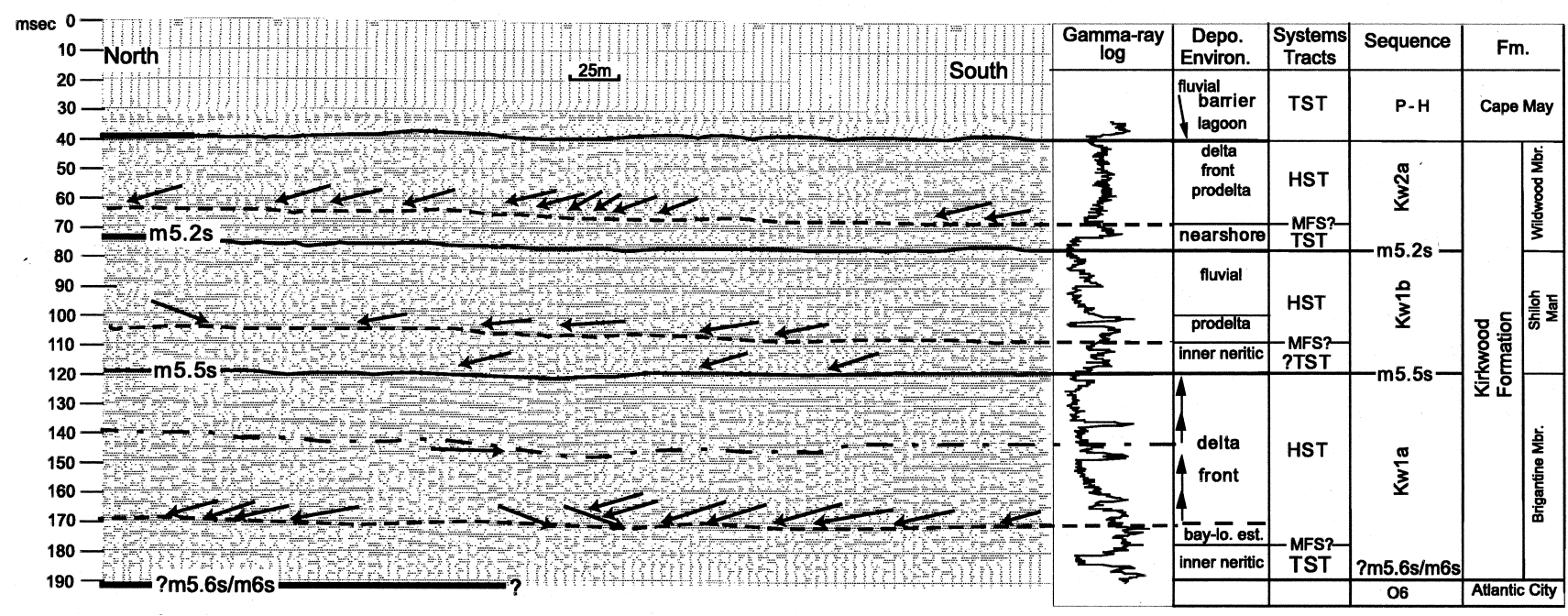

Fig. 6. Land seismic profile crossing the Leg 150X Island Beach site. Seismic data are after Miller et al. (1996c). Insert map shows location of the Leg 150X Island Beach (IB) borehole, the land seismic profile, and offshore CH0698 line 14. Lithology, gamma log, sequence stratigraphic interpretations, depositional environments, systems tract interpretations, and ages are derived from the Island Beach site (Miller et al., 1997a). Sequence boundaries m5.2s, m5.5s are imaged on the profile. Solid lines represent sequence boundaries, dashed lines are MFS, dotted lines are other surface identified on the profiles that reside within the HST. See text for description of seismic interpretation. 


\section{Results}

\subsection{Identifying Lower Miocene sequences in offshore profiles}

We used seismic sequence analysis to identify several well-developed sequence boundaries in offshore data on the basis of offlaping, downlaping, and onlaping reflector geometries (Figs. 4, 7 and 8). Five sequence boundaries are expressed on each of the northern CH0698 dip lines we investigated, while an older, sixth sequence boundary appears on the two northernmost lines (Fig. 4). Onlap and erosional truncations outline the sequence-bounding reflections seaward of the clinoform inflection point of each sequence boundary ${ }^{1}$ (e.g. Fig. 7). Erosional terminations of underlying reflectors identify sequence-bonding surfaces landward of the clinoform inflection points. Select intra-sequence reflectors define system tracts (Van Wagoner et al., 1988) as follows: a key surface (maximum flooding surface [MFS]) divides a thin interval of parallel reflectors below (termed the transgressive systems tract [TST]) from a generally thicker, prograding high stand systems tract (HST) above. Lowstand systems tract (LST) have not been identified on the seismic profiles studied so far.

We correlate five sequence boundaries defined on CH0698 profiles as Lower Miocence and one as Oligocene. In keeping with former nomenclature, we name the Lower Miocene sequence boundaries $\mathrm{m} 5 \mathrm{~s}, \mathrm{~m} 5.2 \mathrm{~s}, \mathrm{~m} 5.4 \mathrm{~s}, \mathrm{~m} 5.5 \mathrm{~s}$, and $\mathrm{m} 6 \mathrm{~s}$. The subscript 's' for shelf, distinguishes each from the m5, m5.2 etc. reflections whose ages were determined by samples from the slope, and this distinction emphasizes that we have now firmly linked these surfaces to shallow-water lithologies and ages.

\subsection{Correlating offshore seismic sequences to onshore sites}

Prior to the present study, there were significant uncertainties in the relationship of reflections beneath

\footnotetext{
${ }^{1}$ This is the point of maximum change in slope associated with a clinoform geometry. It has been termed shelf edge (Schlee, 1981), depositional coastal break (Vail, 1987), depositional shoreline break (Posamentier and Vail, 1988), shelf break (Van Wagoner et al., 1988), clinoform breakpoint (Fulthorpe and Austin, 1998; Fulthorpe et al., 1999), and clinoform inflection point (this study).
}

the shelf with surfaces drilled in onshore sites and reflections beneath the slope. Our study provides first-order correlations of sequence-bounding reflections beneath the inner shelf with onshore sequence boundaries (Fig. 2), confirming that reflections $\mathrm{m} 5 \mathrm{~s}$, $\mathrm{m} 5.2 \mathrm{~s}, \mathrm{~m} 5.4$, and $\mathrm{m} 6$ correlate with the base of $\mathrm{Kw} 2 \mathrm{~b}$, $\mathrm{Kw} 2 \mathrm{a}, \mathrm{Kw} 1 \mathrm{c}$, and $\mathrm{Kw} 0$, respectively.

The Island Beach sonic log allowed us to correlate seismic sequences recognized on the $\mathrm{CH} 0698$ profiles into the onshore boreholes in two ways. First, the sonic log provided the means to construct a synthetic seismogram that we compared with the point of closet approach on offshore line 14 (a distance of roughly 1500 m, Fig. 4, location map Fig. 6). Second, because it agreed so closely with the ACOW2 check shot velocity data (Fig. 5a) we were confident that our depthtime conversions were reliable.

The Island Beach, ACOW2, and Atlantic City sites date the upper two seismic surfaces, $\mathrm{m} 5 \mathrm{~s}$ and $\mathrm{m} 5.2 \mathrm{~s}$; these bracket the Kw2a sequence defined onshore (Figs. 2, 4 and 9). The underlying seismic boundary, $\mathrm{m} 5.4 \mathrm{~s}$, is truncated by $\mathrm{m} 5.2 \mathrm{~s}$ seaward of Island Beach and Atlantic City. Its location in ACOW2 indicates a correlation with the basal sequence boundary of onshore Kw1c (Fig. 2). The only other place that $\mathrm{Kw} 1 \mathrm{c}$ has been sampled is in the Cape May borehole; consistent with this fact, line 27/9 (Fig. 9) shows that this sequence pinches out $\sim 17 \mathrm{~km}$ downdip of Atlantic City. Sequence boundary $\mathrm{m} 5.4 \mathrm{~s}$ is provisionally correlated with slope reflection m5.4 (Fig. 2) of Mountain et al. (1994). The next oldest boundary, m5.5s, corresponds to the base of the Kw1b sequence (Miller et al., 1994, 1997; Sugarman and Miller, 1997; Sugarman et al., 1997).

Comparison of the synthetic seismogram with the CH0698 high-resolution profiles allows dating of the two oldest clinoforms on the seismic grid. A sequence-bounding surface recognized on each of the $\mathrm{CH} 0698$ profiles, reflection m6s, can be traced shoreward to the Island Beach (Fig. 7), Atlantic City (Fig. 8), and AMCOR6011 (Fig. 1) boreholes and correlated to the Oligocene/Miocene boundary (Fig. 2). At this time, we cannot trace this sequence boundary to the slope and tie it to Leg 150 slope boreholes, but stratigraphic placement and age make it the precise equivalent of slope reflection m6. At the Atlantic City borehole, m6s correlates with the base of onshore sequence Kw0. This surface could be a 

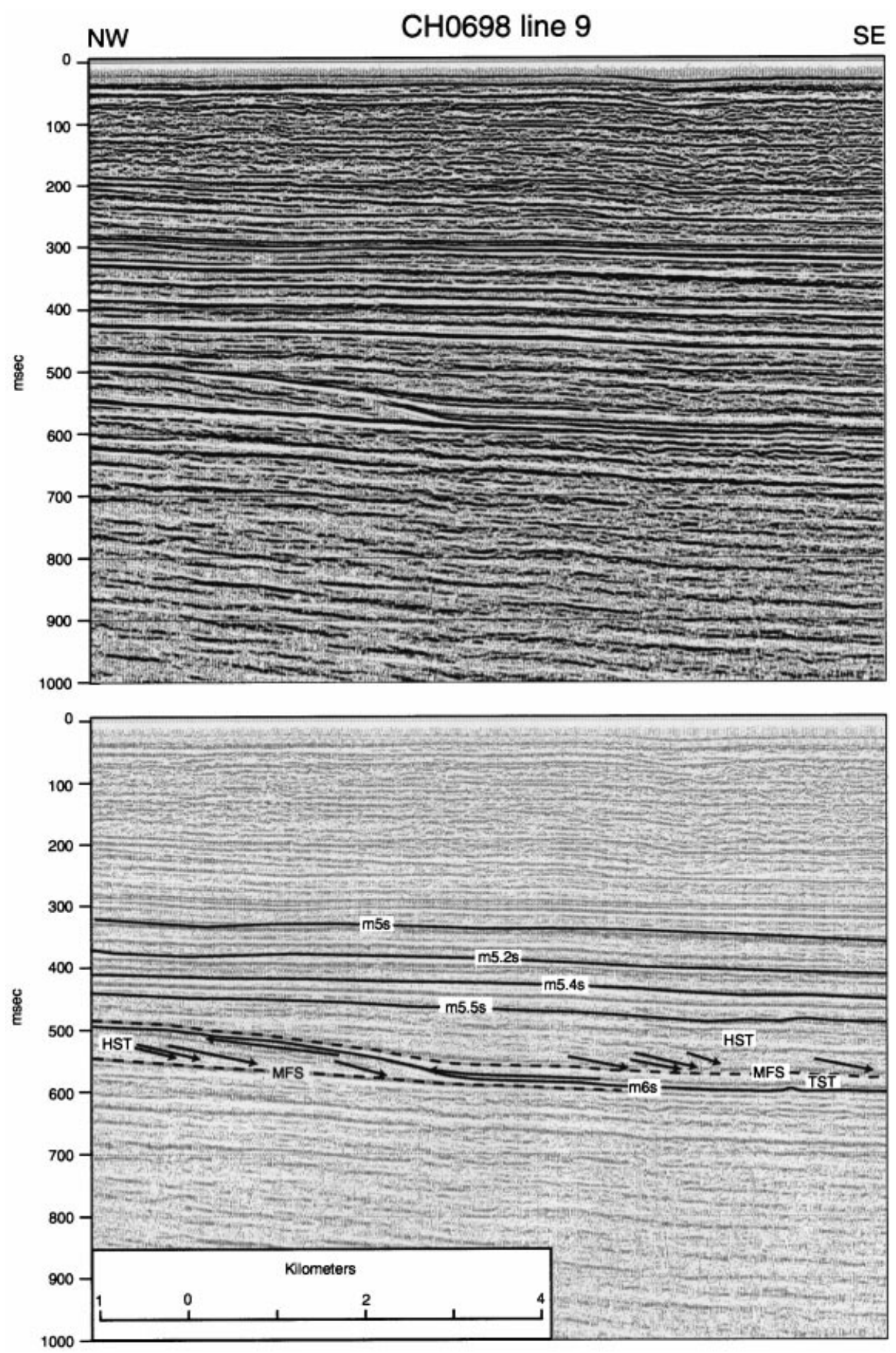

Fig. 7. Seismic dip profile CH0698 line 9 showing onlap, offlap, and erosional truncations used in defining the m6s seismic sequence boundary. Onlap on the m6s surface defines the Transgressive Systems Tract (TST). The maximum flooding surface (MFS, dashed line) separates the TST from the Highstand Systems Tract (HST). Offlap representing seaward sediment progradation defines the HST. Offlap beneath the m6s boundary represents Oligocene progradation. 


\section{Oc270 line 529}
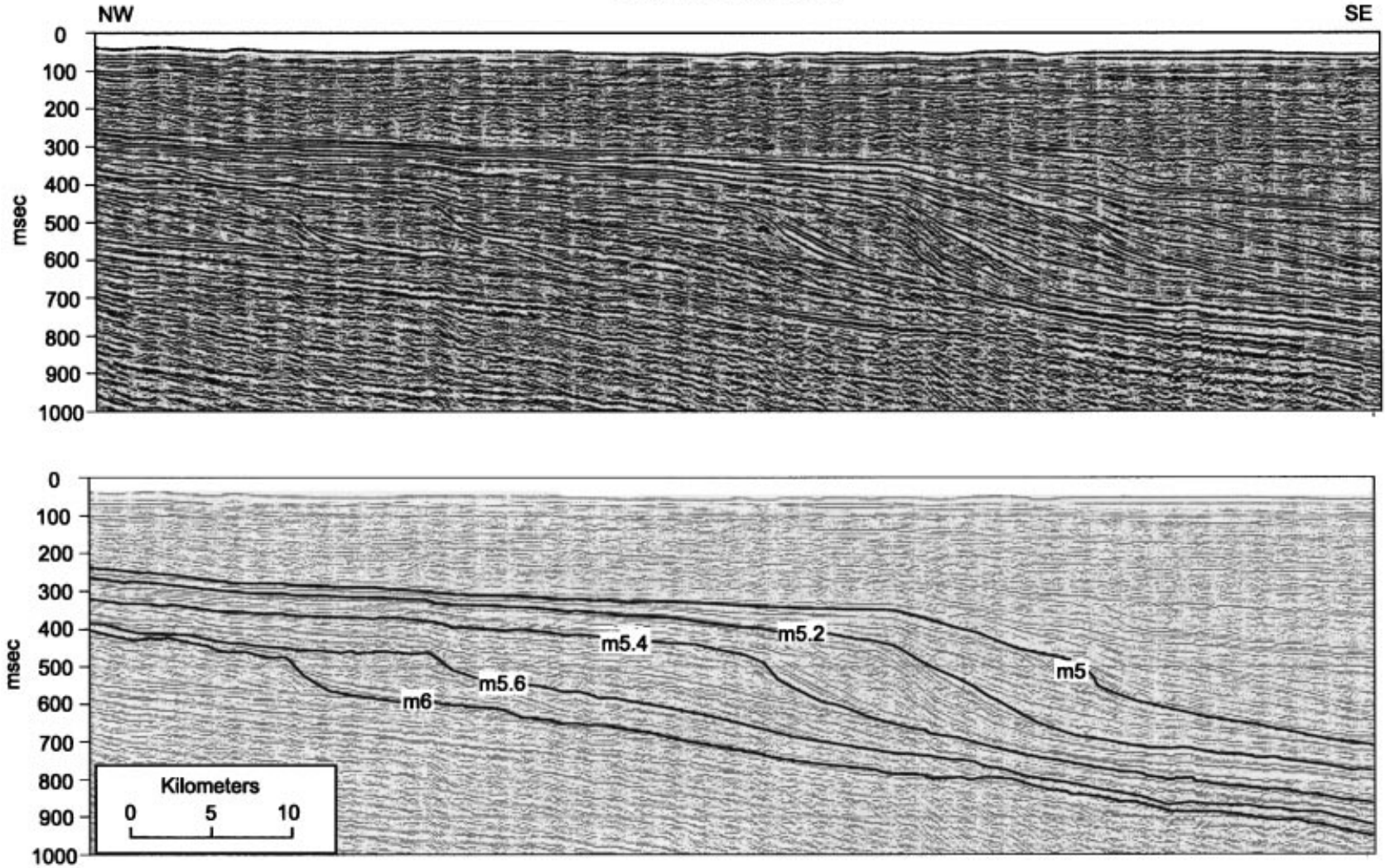

Fig. 8. Seismic dip profile Oc270 line 529 depicting the Lower Miocene seismic sequences boundaries m6, m5.6, $\mathrm{m} 5.4$, $\mathrm{m} 5.2$, and $\mathrm{m} 5$ from the interpretation of N. Christie-Blick et al. (pers. comm.). Note the similar spacing and morphology of these seismic boundaries to m6s, m5.5s, m5.4s, m5.2s and m5s on Fig. 9 from the CH0698 data. Line 529 images the same area as CH0698 data (Fig. 9). Scale same as Fig. 9. 


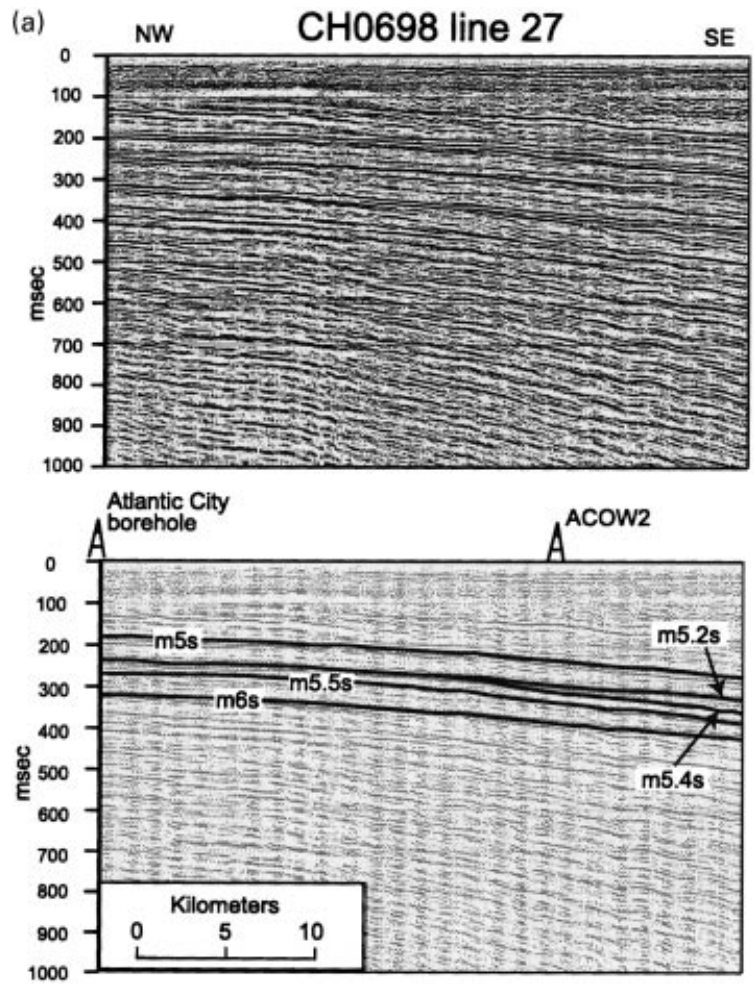

Fig. 9. Seismic dip profile CH0698 line 27/9 showing the shelfdefined $\mathrm{m} 6 \mathrm{~s} \mathrm{~m} 5.5 \mathrm{~s}, \mathrm{~m} 5.4 \mathrm{~s}, \mathrm{~m} 5.2 \mathrm{~s}$ and $\mathrm{m} 5 \mathrm{~s}$ seismic sequence boundaries. Atlantic City borehole and ACOW2 well, located on Fig. 9a, were used in dating these seismic sequence boundaries. Compare the spacing and morphology of these seismic boundaries to $\mathrm{m} 6$, $\mathrm{m} 5.6, \mathrm{~m} 5.4, \mathrm{~m} 5.2$, and $\mathrm{m} 5$ on Fig. 8 from the Oc270 line 529. Scale same as Fig. 8. Fig. 9a is the updip part of section, imaged on line 27, that is shown in Fig. 9b.

concatenation of sequence boundaries m6s and the younger m5.6s because the Kw0 sequence is absent at Island Beach and at Atlantic City is only $\sim 9 \mathrm{~m}$ thick (Miller et al., 1994). Surface m6 was not penetrated by ACOW2.

The oldest clinoform inflection identified in the CH0698 grid lies beneath reflection m6s, yet above the projection of slope reflection o1 (lowermost Oligocene; Mountain et al., 1994; Miller et al., 1996, 1998) from the Island Beach site. It is only imaged on the two northern CH0698 lines, 17 (Fig. 4) and 19 (not shown here). The precise correlation of this sequence boundary with the onshore Oligocene sequences of Pekar et al. (1997) and Pekar et al. (2000) is not certain at present. Nevertheless, the CH0698 data clearly image prograding Oligocene clinoformal wedges beneath the inner shelf, corroborating inferences based on the onshore coastal plain boreholes (Pekar et al., 2000).

\subsection{Correlations with slope seismic sequences}

By dating the nearshore sequences, we provide age correlations for shelf sequence boundaries with slope reflections that is independent of seismic tracing. In particular, the Lower Miocene seismic surfaces that were dated on the New Jersey slope (Miller et al., 1996b) required tracing more than $100 \mathrm{~km}$ to the inner shelf, where they exhibit stratal geometries that can be seismically defined as sequence boundaries. We correlate four sequence boundaries defined with $\mathrm{CH} 0698$ profiles with four sampled in ODP Leg 150 boreholes, and named (from youngest to oldest) $\mathrm{m} 5$, m5.2, m5.4, and m6, (Mountain et al., 1994). The fifth sequence that we recognize is Oligocene; seismic resolution with available data on the slope precludes a confident recognition of Oligocene reflections that can be traced to the inner shelf (Mountain et al., 1994).

One shelf reflection, $\mathrm{m} 5.5 \mathrm{~s}$, does not have a previously identified equivalent on the slope (Mountain et al., 1994). However, glauconite abundances at Site 904 show a large coeval peak (Miller, unpublished data); such peaks are commonly associated with sequence boundaries on the slope. Although this is speculative at this point, we can unequivocally define a previously unrecognized seismic sequence beneath the shelf, date it as $20.2 \mathrm{Ma}$ by correlating it with Atlantic City Sr-isotoptic stratigraphy (Miller et al., 1997; Sugarman et al., 1997), correlate it with the Kw1a/Kw1b sequence recognized in onshore boreholes, and correlate it with the slope glauconite peak.

The shelf sequence boundaries and slope reflections appear to be causally linked. Although reflections on the slope lack definitive geometries criteria of sequence boundaries, they have been found to be commonly associated with evidence for downslope sediment transport (Mountain et al., 1994; Miller et al., 1998). More importantly, Miller et al. (1996b, 1998) showed that these surfaces correlated with glacioeustatic variations inferred from $\delta^{18} \mathrm{O}$ studies, implicating them as records of sea-level lowering. We suggest that as more $\mathrm{CH} 0698$ lines are processed and loop-correlated through close seismic lines from 

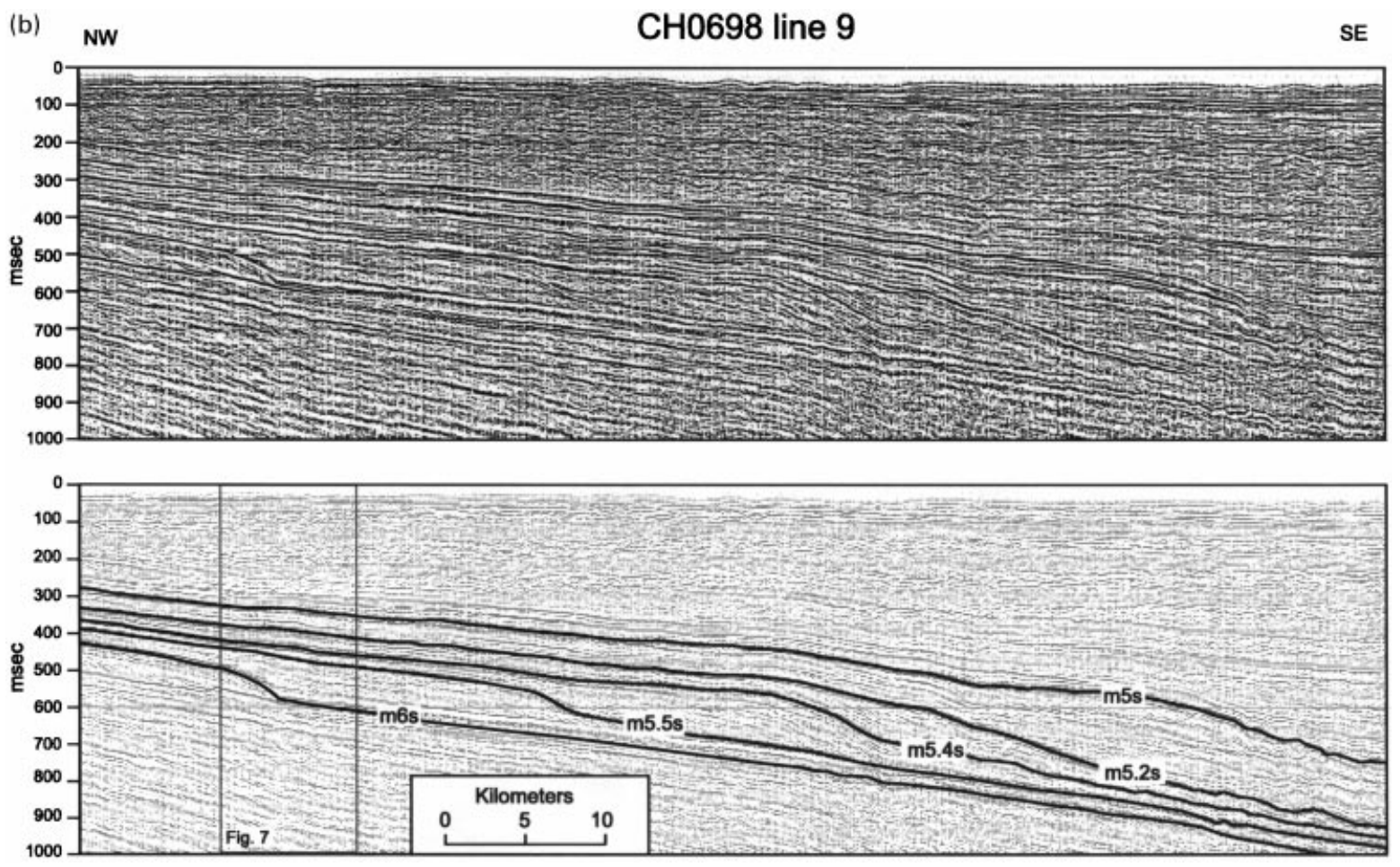

Fig. 9. (continued)

existing grids, a close match will be found for Lower Miocene sequence boundaries. Unambiguous tracing of slope reflections to the inner shelf may be beyond the resolution of current data; however, we suggest that current age correlations between onshore and offshore locations leave little doubt that these physical correlations are correct (Fig. 2).

\subsection{Correlating an onshore profile to the Island Beach borehole}

After tying the onshore sequence boundaries into the inner shelf CH0698 seismic grid, a question remains concerning the correlation of the intrasequence geometries between borehole and seismic profiles. Integration of borehole sedimentary facies with CH0698 seismic facies is premature but a high resolution land seismic profile (Miller et al., 1996c) offers an opportunity to characterize seismically the facies observed in the Island Beach borehole (Miller et al., 1994).

Three sequence boundaries identified in the Island
Beach Leg 150X borehole (23.7, 55.5, and $92.3 \mathrm{~m}$; 78, 182 , and $303 \mathrm{ft}$ ) are associated with the three most prominent and continuous reflections of the onshore profile (Miller et al., 1996c; Fig. 6). These sequence boundaries are associated with the bases of the upper Pleistocene-Holocene, Kw2a, and Kw1b sequences, respectively. Projected in from the Island Beach borehole, the base of Kw1a is apparently below the seismic image at greater than $190 \mathrm{~ms}$ (Fig. 6). Each of these units is described as follows.

\subsection{Upper Pleistocene-Holocene sequence (mostly younger than $5.6 \mathrm{ka}$ )}

The first reflection, identified at $\sim 32 \mathrm{~ms}$ (Fig. 6; Miller et al., 1996c), lies immediately below the contact between sands deposited in beach environments and sandy muds deposited in lagoonal enivornments; it is associated with the top of a "tight" clay. The impedance contrast at the base is associated with a sharp lithologic change from upper PleistoceneHolocene fluvial gravel above to Kirkwood delta 
front sands below. There are hints of channeling on this surface at SP 60 (Fig. 6).

\subsection{Kw2a sequence (16.5-17.8 Ma as dated at other sites)}

Three seismic facies in sequence Kw2a correspond to three environments of deposition inferred from borehole studies. At the base, a distinct, continuous reflection correlates with a sequence boundary in the borehole, although there is no seismic evidence at this site for this being a sequence boundary (Fig. 6). We correlate this surface to m5.2s. Immediately above this, a moderately continuous reflection with downlap coincides with a MFS inferred from core studies. The intervening $10 \mathrm{~ms}$ between the sequence boundary and the MFS consists of sands deposited in nearshore environments. The overlying sections $(15-20 \mathrm{~ms}$ thick) show several downlapping reflectors that appear to prograde to the north (Fig. 6). These prograding lower HST sediments consist of silts deposited in prodelta environments. A thin upper section $(10 \mathrm{~ms})$ that caps the sequence portrays moderately continuous reflections; the associated sediments are sands deposited in delta front environments (upper HST; Fig. 6).

\subsection{Kw1b sequence (19.5-20.1 Ma as dated at other sites)}

The reflection at $120 \mathrm{~ms}$ at north end of the profile is recognized as a seismic sequence boundary by truncation of underlying reflections and possible channeling at SP25 and SP55 (Fig. 6). We correlate it to $\mathrm{m} 5.5 \mathrm{~s}$. A downlap surface at $103 \mathrm{~ms}$ with progradation toward the north correlates with the MFS inferred from the borehole. The intervening section shows a hummocky seismic character with somewhat discontinuous reflections; this TST is associated with sands that were possibly deposited in inner neritic environments. Above the MFS, 15 ms of somewhat discontinuous reflections associated with prodelta silts are overlain by $8 \mathrm{~ms}$ of chaotic reflections associated with fluvial sands. These are capped by two continuous reflections that are also associated with fluvial sands.

\subsection{Kwla (20.1-21.1 Ma as dated at other sites)}

There is distinct downlap on a reflection at $170 \mathrm{~ms}$
(Fig. 6) with general progradation toward the north (and possible bi-directional downlap at SP55). There may be some truncation associated with this surface at SP42; however, it appears to be associated with a regression from inner neritic, slightly glauconitic sands below to estuarine/lagoonal sediments above. Therefore, we interpret it as a MFS. More data are needed to resolve the significance of this surface. Above this, there are two seismic facies separated by a reflection at $145 \mathrm{~ms}$ that correlates with a large gamma ray log increase. The lower facies is associated with strong downlap and discontinuous reflections; the upper facies is associated with stronger, more continuous reflections and is truncated at its top. Both are associated with sands deposited in delta front environments. Sequence boundary m5.6s/ m6s is apparently not seismically resolved as it projects beneath $190 \mathrm{~ms}$.

\section{Discussion}

The Lower Miocene sequences identified in onshore boreholes also correlate to seismically defined sequences in the CH0698 data. Most of the Miocene sequences have been dated at more than one borehole (the $\mathrm{Kw} 1 \mathrm{c}, \mathrm{Kw} 2 \mathrm{c}$, and $\mathrm{Kw}-\mathrm{Cohansey}$ are notable exceptions), lending confidence to the global correlation of the seismically and core-defined sequences (Fig. 2). Still, some sequences identified both onshore and at slope sites do not image as seismic sequence boundaries in the CH0698 data. Slope seismic reflection m5.6 either is not represented or is beneath the resolution of the $\mathrm{CH} 0698$ data. Onshore sequence $\mathrm{Kw} 0$ is absent in the north at both the Island Beach and AMCOR6011 (Miller et al., 1994; Pekar et al., 2000). Farther to the south at Atlantic City, sequence Kw0 is $\sim 9 \mathrm{~m}$ thick (Miller et al., 1994). Tracing the overlying Kwla sequence boundary offshore from Atlantic City does not reveal stratal geometry indicative of a seismic sequence boundary. The thin sequence $\mathrm{Kw} 0$ probably prevents seismic resolution of the equivalents of slope reflections $\mathrm{m} 6$ (correlative to the base of Kw0) and m5.6 (correlative to the base of Kw1a; Fig. 2). Sequence Kw0 thickness southward to Cape May, where it is $\sim 36 \mathrm{~m}$ thick (Miller et al., 1996a). Seismic data from this region have not been processed, although we predict that a 
prominent sequence boundary equivalent to slope reflection $\mathrm{m} 5.6$ and the base of onshore sequence $\mathrm{Kw} 1 \mathrm{a}$ should be present in the southern region of CH0698 data coverage.

Confirming these correlations and resolving outstanding questions outlined above require completing the analysis of $\mathrm{CH} 0698$ data and detailed tracing of Oc270 data, using the dated surfaces from slope Leg 150 and shelf/slope Leg 174A. Initial interpretations of Oc270 line 529 (Figs. 1 and 9: N. Christie-Blick et al., pers. comm., in prep.) show a similar number and spacing of sequences as we observe in CH0698. These surfaces have been tentatively correlated to Ew9009 line 1003 and traced to the slope where they were named $\mathrm{m} 5, \mathrm{~m} 5.2, \mathrm{~m} 5.4,5.6$ and $\mathrm{m} 6$ and tied to Leg 150 drill sites. Loop correlations among the three seismic data sets should substantially improve our understanding of the numbers of sequences and facies variations with sequences. However, these efforts may still yield ambiguous correlations of some reflections due to limitations in the Oc270 dataset (Fulthorpe et al., 1999).

One major difference between the nearshore and slope seismic interpretations requires verification. We identify sequence m5.5s on the CH0698 profiles that appears acoustically similar to reflection m5.6 traced from the slope; however, our age correlations for these two reflections are clearly different (Fig. 2). We believe that this age difference may be real and that $\mathrm{m} 5.5 \mathrm{~s}$ may be a slightly younger sequence boundary than m5.6. Reflector m5.5s clearly correlates with the basal Kw1b sequence boundary (i.e. it can be clearly traced to Kwlb at both Island Beach and Atlantic City); it also appears to correlate with a minor global $\delta{ }^{18} \mathrm{O}$ increase (Milaa; Fig. 2). Reflector m5.6 apparently correlates with the basal Kw1a onshore sequence; first-order correlation shows that $\mathrm{m} 5.6$ is associated with the global Mila $\delta^{18} \mathrm{O}$ increase on the slope (Miller et al., 1998) (Fig. 2). We plan to test the differences between these two sequences when more $\mathrm{CH} 0698$ profiles are processed and displayed, and by (re)tracing reflection m5.6 from the slope to the CH0698 seismic grid.

\section{Conclusions}

This study presents seismic profiles that fill the data gap between the onshore ODP Leg 150X boreholes and New Jersey shelf and slope investigations encompassing the Ew9009 and Oc270 seismic grids and Legs 150 and 174A boreholes. Seismic stratal geometries defined six sequence boundaries on the CH0698 seismic profiles: m5s, $\mathrm{m} 5.2 \mathrm{~s}, \mathrm{~m} 5.4 \mathrm{~s}, \mathrm{~m} 5.5 \mathrm{~s}$ and $\mathrm{m} 6 \mathrm{~s}$, and an unnamed Oligocene sequence boundary. These seismic sequences correlated with Lower Miocene sequences boundaries recognized in onshore boreholes as the base of Kw2b, Kw2a, Kw1c, Kw1b, and Kw0, respectively. These lithostratigraphically and paleontologically recognized sequences, associated with global $\delta^{18} \mathrm{O}$ increases (Miller et al., 1998), now are tied to seismically defined sequence boundaries across the present day shelf. This further substantiates the influence of global sea-level change with New Jersey passive margin development.

CH0698 profiles provides a direct tie between onshore boreholes and shelf seismic grids that can then be traced to slope borehole control. The nearshore/onshore sequence boundaries outlined in this study correlate with four of five Lower Miocene reflections dated on the slope; $\mathrm{m} 5, \mathrm{~m} 5.2, \mathrm{~m} 5.4$, and $\mathrm{m} 6$; the fifth surface, m5.5s, has not been identified previously on the slope. Directly carrying the CH0698 and onshore correlations out to slope dated sites (Leg 150 and $174 \mathrm{~A}$ ) will require tracing through the existing Oc270 database, which remains to be completed. CH0698 data define a sixth surface documenting that Oligocene clinoformal wedges occur in the nearshore region as predicted by Pekar et al. (1997) and Pekar et al. (2000). Still questions remain; for example reflections $\mathrm{m} 5.6$ and $\mathrm{m} 6$ are clearly defined in slope data, whereas the reflections $\mathrm{m} 5.6 \mathrm{~s}$ and $\mathrm{m} 6 \mathrm{~s}$ are concatenated in the CH0698 data. Further processing of the CH0698 data should help to resolve this and other issues.

Preliminary CH0698 profile analysis has outlined Lower Miocene TSTs and HSTs that were recognized in the Island Beach, Atlantic City and Cape May boreholes. Land seismic data clearly image the various intra-sequence sedimentary facies documented at the Island Beach site. Future work will complete the definition of systems tracts and carry these intra-sequence facies interpretations offshore onto the CH0698 grid. 


\section{Acknowledgements}

We thank P. Buhl for invaluable help with thorny seismic data collection and processing issues in shallow water, the scientific party of CH0698 (B. Sheridan, S. Carbotte, B. Cramer, J. Floyd), J. Austin and the UTIG team for collaboration in collection and processing of the Oc270 data, N. Christie-Blick for helping to carry Ew9009 seismic interpretations to the CH0698 grid, and J. Alsop for help in seismic processing. Special thanks to J. Metzger and P. Flemings (Penn State University) for help in computing synthetic seismograms. CH0698 was supported by NSF OCE97-02191. The Oc270 seismic grid was collected in 1995 under grant NOOO14-96-1-0377 from the US Office of Naval Research in support of its STRATAFORM initiative.

Additional support was provided by National Science Foundation grants (NSF EAR94-17108 and EAR97-08664 to K. Miller) and the New Jersey Geological Survey. Cores were obtained by the New Jersey Coastal Plain Drilling Project (ODP Legs 150X and 174AX) supported by the NSF Continental Dynamics and Ocean Drilling Programs. We thank P. Sugarman and S. McGeary for discussion and encouragement, B. Whiting and C. Fulthorpe and M. Katz for helpful reviews, and M. Segall and W.B. Harris for editorial control. This is LDEO contribution number $\mathrm{xxxx}$.

\section{References}

Austin, J.N., Fulthorpe, C.S., Mountain, G.S., Orange, D., Field, M.E., 1996. Continental margin seismic stratigraphy: Assessing the preservation potential of heterogeneous geologic processes operating in continental shelves and slopes. Oceanography 9 , 173-177.

Austin, J.A., Christie-Blick, N., Malone, M.J., Berne, S., Borre, M.K., Claypool, G., Damuth, J., Delius, H., Dickens, G., Flemings, P., Fulthorpe, C., Hesselbo, S., Hoyanagi, K., Katz, M., Krawinkel, H., Major, C., McCarthy, F., McHugh, C., Mountain, G., Oda, H., Olson, H., Pirmex, C., Savrda, C., Smart, C., Sohl, L., Vanderaveroet, P., Wei, W., Whiting, B., 1998. Continuing the New Jersey Mid-Atlantic sea-level transect, Proc. Ocean Drill. Program, Initial Reports, 174A, College Station, TX (Ocean Drilling Program), 324p.

Bartek, L.R., Vail, P.R., Anderson, J.B., Emmet, P.A., Wu, S., 1991. Effect of Cenozoic ice sheet fluctuations in Antarctica on the stratigraphic signature of the Neogene. J. Geophys. Res. 96, $6753-6778$.
Christie-Blick, N., Driscoll, N.W., 1995. Sequence stratigraphy. Annu. Rev. Earth Planet. Sci. 23, 451-478.

Fulthorpe, C.S., Austin Jr, J.A., 1998. The anatomy of rapid margin progradation: three-dimensional geometries of Miocene clinoforms, New Jersey margin. Am. Assoc. Petrol. Geol. 82, 251273.

Fulthorpe, C.S., Austin Jr, J.A., Mountain, G.S., 1999. Buried fluvial channels off New Jersey: did sea-level lowstands expose the entire shelf. Geology 27, 203-206.

Greenlee, S.M., Moore, T.C., 1988. Recognition and interpretation of depositional sequences and calculations of sea level changes from stratigraphic data-offshore New Jersey and Alabama Tertiary. In: Wilgus, C.K., Hastings, B.S., Kendall, C.G.St.C., Posamentier, H.W., Ross, C.A., Van Wagoner, J.C. (Eds.), Sea Level Changes: An Integrated Approach, Soc. Econ. Paleontol. Mineral, Spec. Publ., 42, pp. 329-353.

Greenlee, S.M., Schroeder, F.W., Vail, P.R., 1988. Seismic stratigraphic and geohistory analysis of Tertiary strata from the continental shelf off New Jersey-Calculation of eustatic fluctuations from stratigraphic data. In: Sheridan, R., Grow, J. (Eds.), Atlantic Continental Margin, US, Geol. Soc. Am., DNAG ser., 1988. pp. 437-444.

Greenlee, S.M., Devlin, W.J., Miller, K.G., Mountain, G.S., Flemings, P.B., 1992. Integrated sequence stratigraphy of Neogene deposits, New Jersey continental shelf and slope: comparison with the Exxon model. Geol. Soc. Am. Bull. 104, 1403-1411.

Hathaway, J.C., Schlee, J.S., Poag, C.W., Valentine, P.C., Weed, E.G.A., Bothner, M.H., Kohout, F.A., Manheim, F.T., Schoen, R., Miller, R.E., Schultz, D.M., 1976. Preliminary summary of the 1976 Atlantic Margin Coring Project of the US Geological Survey. US Geol. Sur. Open-File Rep., 76-844, 207pp.

Hathaway, J.C., Poag, C.W., Valentine, P.C., Miller, R.E., Schultz, D.M., Manheim, F.T., Kohout, F.A., Bothner, M.H., Sangrey, D.W., 1979. US Geological Survey core drilling on the Atlantic shelf. Science 206, 515-527.

Metzger, J., Flemings, P.B., Christie-Blick, N., Mountain, G.S., Austin, J.A. Jr., Hesselbo, S., 2000. Integration of seismic, $\log$, and core data for late Miocene to Pleistocene sequence at the New Jersey outer continental shelf (ODP Leg 174A, Sites 1071 and 1072), Sed. Geology, special issue, "OnshoreOffshore correlations, this volume.

Miller, K.G., 1997. Coastal plain drilling and the New Jersey Sealevel Transect, Proc. ODP, Sci. Results, 150X: College Station, TX (Ocean Drilling Program), p. 3-12.

Miller, K.G., Mountain, G.S., 1994. Global sea-level change and the New Jersey margin, Proc. Ocean Drill. Program, Initial Reports, 150 , pp. 11-20.

Miller, K.G., Mountain, G.S., 1996. The Leg 150 Shipboard Party, and Members of the New Jersey Coastal Plain Drilling Project, Drilling and dating New Jersey Oligocene-Miocene sequences: Ice volume, global sea level, and Exxon records. Science 271, 1092-1094.

Miller, K.G., Snyder, S.W. (Eds.), 1997. Proc. Ocean Drill. Program, Sci. Results, 150X, College Station, TX (Ocean Drilling Program), 388p.

Miller, K.G., Wright, J.D., Fairbanks, R.G., 1991. Unlocking the Ice 
House: Oligocene-Miocene oxygen isotopes, eustasy, and margin erosion. J. Geophy. Res. 96, 6829-6848.

Miller, K.G., Aubrey, M.-P., Browning, J.V., Burkry, D., Burckle, L.D., Feigenson, M.D., Gross, M., Gwynn, D., Kent, D.V., Liu, C., Mullikin, L., Queen, D., Sugarman, P. Van Fossen, M., 1994. New Jersey Coastal Plain, Proc. Ocean Drill. Program, Initial Reports, 150X, College Station, TX (Ocean Drilling Program), $59 \mathrm{p}$.

Miller, K.G., Liu, C., Browning, J.V., Pekar, S., Sugarman, P.J., Van Fossen, M.C., Mullikin, L., Queen, D., Feigenson, M.D., Aubry, M.-P., Burckle, L.D., Powars, D., Heibel, T., 1996a. Cape May site report. Proc. Ocean Drill. Program, Init. Repts., 150X, 59pp.

Miller, K.G., Liu, C., Feigenson, M.D., 1996b. Oligocene to middle Miocene Sr-isotropic stratigraphy of the New Jersey continental slope. Proc. Ocean Drill. Program Sci. Results 150, 97-114.

Miller, K.G., Rufolo, S., Sugarman, P.J., Pekar, S.F., Browning, J.V., Gwynn, D.W., 1997. Early to middle Miocene sequences, systems tracts, and benthic foraminiferal biofacies. Proc. Ocean Drill. Program, Sci. Results, 150X, pp. 169-186.

Miller, K.G., Mountain, G.S., Browning, J.V., Kominz, M.A., Sugarman, P.J., Christie-Blick, N., Katz, M.E., Wright, J.D., 1998. Cenozoic global sea level, sequences, and the New Jersey transect: results from coastal plain and continental slope drilling. Rev. Geophys. 36, 569-601.

Miller, P.T., McGreary, S., Madsen, J.A., 1996. High resolution seismic reflection images of New Jersey coastal aquifers. J. Environ. Engineer. Geophys. 1, 55-66.

Mitchum, R.M. Jr., 1977. Seismic stratigraphy and global changes of sea level, Part 11: Glossary of terms used in seismic stratigraphy. In: Payton, C.E. (Ed.), Seismic Stratigraphy-Applications to Hydrocarbon Exploration, Am. Assoc. Petrol. Geol. Mem., 26, pp. 205-212.

Mountain, G.S., Miller, K.G., Blum, P., Alm, P.-G., Aubrey, M.-P., Burckle, L.H., Christensen, B.A., Compton, J., Damuth, J.E., Deconinck, J.-F., de Verteuil, L., Fulthorpe, C.S., Gartner, S., Guerin, G., Hesselbo, S.P., Hoppie, B., Katz, M.E., Kotake, N., Lorenzo, J.M., McCracken, S., McHugh, C.M., Quayle, W.C., Saito, Y., Snyder, S.W., ten Kate, W.G., Urbat, M., Van Fossen, M.C., Vecsei, A., 1994. New Jersey continental slope and rise, Proc. Ocean Drill. Program., Initial Reports, 150, College Station, TX (Ocean Drilling Program), 885p.

Owens, J.P., Sugarman, P.J., Sohl, N.F., Orndorff, R.C., 1995.
Geologic map of New Jersey: Southern Sheet. US Geol. Surv. Open-File Rep. 95-254 scale 1:100,000.

Owens, J.P., Miller, K.G., Sugarman, P.J., 1997. Lithostratigraphy and paleoenvironments of the Island Beach borehole. New Jersey Coastal Plain, Proc. Ocean Drill. Program, Sci. Results, 150X, pp. 15-24.

Pekar, S.F., Miller, K.G., Browning, J.V., 1997. New Jersey Coastal Plain Oligocene sequences. ODP Leg 150X, Proc. Ocean Drill. Program, Sci. Results, 150X, pp. 187-206.

Pekar, S.J., Miller, K.G., Kominz, M.A., 2000. Reconstructing the stratal geometry of new jersey oligocene sequences: resolving a patchwork distribution into a clear pattern of progradation. Sed. Geology 134, 93-109 (this issue).

Posamentier, H.W., Vail, P.R., 1988. Eustatic controls on clastic deposition II-sequence and systems tract models. In: Wilgus, C.K., Hastings, B.S., Kendall, C.G.St.C., Posamentier, H.W., Ross, C.A., Van Wagoner, J.C. (Eds.), Soc. Econ. Paleontol. Mineral, Spec. Pub., 42, pp. 125-154.

Schlee, J.S., 1981. Seismic stratigraphy of Baltimore Canyon Trough. Am. Assoc. Petrol. Geol. Bull. 65, 26-53.

Sea Level Working Group, 1992. JOIDES Journal, 18 (3), 28-36.

Sugarman, P.J., Miller, K.G., 1996. Correlation of Miocene sequences and hydrogeologic units, New Jersey Coastal Plain, Sedimentary Geology, 108, 3-18.

Sugarman, P.J., McCartan, L., Miller, K.G., Feigenson, M.D., Pekar, S., Kistler, R.W., Robinson, A.G., 1997. Strontium-isotopic correlation of Oligocene to Miocene sequences, New Jersey and Florida, Proc. Ocean Drill. Program, Sci. Results, 150X, pp. 147-159.

Vail, P.R., 1987. Seismic stratigraphy interpretation using sequence stratigraphy. Part 1: seismic stratigraphy interpretation procedure. In: Bally, A.W. (Ed.), Atlas of seismic stratigraphy, vol. 1, AAPG Studies in Geology, 27, pp. 1-10.

Van Wagoner, J.C., Posamentier, H.W., Mitchum, R.M., Jr., Vail, P.R., Sarg, J.F., Loutit, T.S., Hardenbol, J., 1988. An overview of the fundamentals of sequence stratigraphy and key definitions. In: Wilgus, C.K., Hastings, B.S., Kendall, C.G.St.C., Posamentier, H.W., Ross, C.A., Van Wagoner, J.C. (Eds.), Soc. Econ. Paleontol. Mineral., Spec. Publ., 42, pp. 39-46.

Waldner, J.S., Hall, D.W., 1991. A marine seismic survey to delineate Tertiary and Quaternary stratigraphy of Coastal Plain sediments offshore of Atlantic City, New Jersey, NJ Geol. Surv. GSR 26, 15pp. 